\title{
UMA INCURSÃO ÀS FONTES SOBRE O MOVIMENTO OPERÁRIO DE RIO GRANDE NO INÍCIO DO SÉCULO XX
}

Eliana Gasparini Xerri ${ }^{1}$

A cidade de Rio Grande, localizada no extremo sul do estado do Rio Grande do Sul, viveu momentos significativos no que tange à vida operária nas duas primeiras décadas deste século.

Era uma importante área econômica, com complexo industrial e comercial de elevado porte para as condições da cidade e da época. Essa situação econômica, conjugada à existência do único porto marítimo do estado, favoreceu a reestruturação urbana e tornou a cidade atrativa para novos investidores e para o operariado.

O movimento operário de Rio Grande apresentou características semelhantes às do operariado nacional e estadual, mas teve, concomitantemente, particularidades, dentre elas, a mobilização maior nos anos de 1918 e 1919, enquanto os operários estaduais demonstraram maior mobilização no ano de 1917.

A imprensa operária constitui, em tese, a principal fonte de informações para o conhecimento da realidade em que viviam os operários. Mas foi a imprensa não-operária que se tornou reveladora, pois como estava voltada a um público maior não possuía o compromisso doutrinador próprio dos jornais operários, além de expressar opiniōes dos grupos sociais a que estava vinculada.

Mestre em História pela PUCRS, professora de $1^{2}, 2^{\underline{a}}$ Graus e no Núcleo Universitário de Nova Prata-UCS. 
Foram utilizados também processos-crime, por contribuírem no preenchimento de algumas lacunas deixadas pela imprensa, tornandose demonstrativos dos conflitos vivenciados pelos operários num cotidiano marcado pela insegurança e por dificuldades. Os pedidos de habeas-corpus revelam motivos de prisões e mesmo informações dos fatores desencadeadores das greves, uma vez que através da imprensa nem sempre isso era perceptível.

A parcialidade do conhecimento do meio operário de Rio Grande nas duas décadas iniciais deste século deve-se às dificuldades apresentadas pelas fontes, ao silêncio que as cerca, no sentido de que a imprensa não-operária muitas vezes dizia algo em nome dos operários sem permitir que esses expressassem suas verdades. O silêncio também foi imposto pelo desaparecimento de exemplares dos jornais operários, cujo vazio é lastimável.

O parque industrial de Rio Grande era formado por fábricas que atuavam em diversos ramos. Sua anterioridade em relação à industrialização da capital do estado ajudou para que sua produção se voltasse ao mercado nacional, enquanto aquele estava voltado ao mercado regional.

O capital empregado nas indústrias de Rio Grande era, em primeiro lugar, de origem nacional e, em segundo, estrangeira, sendo que este predominou nos setores portuários, representado pelo capital francês através da Companhia Francesa e na instalação do Frigorífico Swift, de capital norte-americano.

A composição da classe operária abrangia elementos provenientes da época da escravidão, advindos da área rural e do setor urbano e foi, desde cedo, composta por mulheres e crianças, utilizadas principalmente nas indústrias têxteis, por receberem salários menores. As crianças eram, muitas vezes, recrutadas junto a orfanatos e casas de caridade e em algumas situações exerciam suas funções de forma gratuita em troca de alimentação.

Os integrantes do movimento operário agiram mediante a sua desconfortável realidade e defenderam formas diferenciadas de organização e de atuação.

Dentre as formas de atuação do operariado encontram-se as idéias defendidas pelos socialistas e anarquistas, que foram as que tiveram maior aceitação. Possuíam divergências de organização e atuação, mas ambas concordavam com a "necessidade de uma jornada de 
luta, o que evidencia a identidade de aspirações que unificam o movimento operário." 2

A formação e organização do movimento operário contou nos primeiros anos da República Velha com forte presença de idéias socialistas, chamadas por alguns de social-democratas. Essa orientação já se fazia sentir desde as décadas finais do século passado e, juntamente com as anarquistas, predominaram no movimento operário do período.

$\mathrm{O}$ anarquismo teve maior aceitação, porque negava o poder político-partidário. Havia desta forma identificação com os operários, que não possuíam representatividade parlamentar nem encontravam canais de comunicação entre os poderes constituídos. Sua aceitação se deu também porque as formas paternalistas comuns ao período da escravidão não mais existiam e os operários sentiam-se desprotegidos, ao mesmo tempo que estavam desobrigados à obediência. Logo, a idéia da ausência de autoridade e de uma sociedade livre exercia sobre o operariado certo fascínio.

A presença do anarquismo se fez sentir de forma mais atuante a partir da fundação da União Operária Internacional em 1902. Essa entidade agrupava associações de ramos afins. Desde 1906, sob a influência do I Congresso Operário realizado no Rio de Janeiro, a direção do movimento operário gaúcho passou a seguir as idéias defendidas pelos anarquistas.

De importância fundamental para o movimento operário gaúcho foi a criação da Federação Operária do Rio Grande do Sul (FORGS). Essa iniciativa se deve aos socialistas, que procuraram, dessa forma, neutralizar a influência da União Operária Internacional.

A FORGS foi fundada em 1906 e possuía associações federadas em praticamente todo o estado. A penetração gradual das idéias anarquistas no movimento operário enfraqueceu os socialistas, até que em 1911 os anarquistas venceram as eleições para a direção da federação. ${ }^{3}$

2 PETERSEN, Sílvia R. F. Origens do $1^{2}$ de maio no Brasil. Porto Alegre: Ed. da Universidade-UFRGS, 1988.

3 - "O anarquismo no Rio grande do Sul na Primeira República". Revista do IFCH da UFRGS. Porto Alegre, vol. 5, 1991/1992. 
A história do movimento operário em Rio Grande iniciou-se no século passado com a instalação das primeiras indústrias.

Por estar o movimento operário interrelacionado com a questão econômica, é preciso ter presente o que essa área representava para a sua formação e organização. A indústria, como atividade econômica emergente, passou a exercer influência sobre a estrutura urbana, modificando o traçado das cidades, incorporando novos bairros, promovendo modificações infra-estruturais. A influência da industrialização não se limitou à área urbanística, mas penetrou no cotidiano dos cidadãos e também afetou a questão operária.

O processo de industrialização de Rio Grande esteve relacionado a pequenas e grandes fábricas, que trabalhavam produtos da região, em sua grande maioria, e voltavam-se a atender ao mercado nacional. Foi favorecido pela existência do porto, que facilitava a comercialização dos seus produtos com as demais regiões do país. A partir dessas indústrias ocorreu a diversificação nos modos de vida, nos costumes dos habitantes.

Se antes a vida girava em torno das atividades agropecuárias, se o comércio era reduzido e o porto ineficiente, com a implantação das oficinas e das fábricas, aos poucos, o cotidiano foi se transformando. Essas transformações podem ser observadas desde as áreas povoadas da cidade até o uso de novos produtos no comércio, a necessidade de melhorias nas instalações urbanas e o surgimento e fortalecimento gradual de uma nova categoria social urbana, o operariado industrial, que juntamente com os demais diversificaram o cotidiano riograndino em várias ocasiões.

Nesse contexto a participação da imprensa foi fundamental. Graças à existência do porto, Rio Grande era privilegiada quanto ao recebimento de notícias. Os jornais ali chegavam sem a necessidade de Porto Alegre servir como entreposto.

Rio Grande contou desde cedo com a existência da imprensa operária e não-operária. Seus primeiros jornais datam do século passado, como o jornal 28 de Julho, editado por João Evangelhista de Lima Frazão, de caráter operário, cuja data é de $1885 .^{4}$

A imprensa favoreceu a formação de novas idéias e promoveu transformações na cidade de Rio Grande. Não se limitava ao que se

4 Marçal, Joāo Batista. Os anarquistas no Rio Grande do Sul. Porto Alegre: Unidade Editorial, 1995. 
conhece como grande imprensa, por mim chamada de não-operária. Era diversificada, os nomes dos jornais atestam essa variedade e obedeciam a uma certa conformidade com o que traziam os seus textos: A Lucta, O Intransigente, O Bohemio, A Razão, O Artista, Echo Operário, Rio Grande, para citar apenas alguns.

A importância da imprensa fundamenta-se no fato de esclarecer, informar, formar opiniões. Ainda mais se se considerar o fato de que era o único meio de comunicação da época acessível à uma parcela significativa da população. Existiam livros, revistas, mas, devido ao preço, esses eram menos lidos. Havia ainda os folhetos avulsos, muito usados em épocas de paredes, de caráter provisório. O instrumento de comunicação mais difundido era então o jornal.

A existência da imprensa relaciona-se ao grau de desenvolvimento urbano. À medida que a cidade cresce, aumenta a necessidade de comunicação, da mesma forma que a cidade se industrializa, surge a imprensa operária como instrumento de convergência e divergência de idéias, com o objetivo de agrupar operários em torno da realização de seus desejos.

Publicar jornais foi uma das primeiras iniciativas das associações operárias assim que se organizavam. Era imprescindível a existência de algum meio de comunicação entre os trabalhadores.

A edição dos jornais independia da corrente ideológica seguida pelas classes laboriosas: socialistas, libertários, anarcossindicalistas e mais tarde os comunistas.

A imprensa operária de Rio Grande trazia poucas informações a respeito do movimento operário da cidade. Possuía uma variedade de assuntos, dentre eles textos de formação teórica editados em capítulos, peças teatrais, também em capítulos, avisos, a pedidos, notícias sobre acontecimentos ocorridos na Europa. Caracterizam-se também os jornais operários pelo tom propagandístico e doutrinário de suas páginas, onde havia espaço para o chamamento dos operários à união e à necessidade de serem bem informados.

O fato de a maioria da população ser analfabeta, principalmente a pertencente aos grupos menos favorecidos, e dentre eles o operariado, não constituía entrave para o conhecimento do que se passava no meio operário, pois as notícias eram lidas por alguém do grupo e os demais as ouviam, nem o fato de haver estrangeiros, pois eram editados nas línguas de origem do operariado. 
Obedecendo a certa padronização (poucas páginas, veiculação de notícias internacionais, de textos doutrinários, circulação periódica, publicidade praticamente nula, perseguição, empastelamento), os jornais operários possuem grande valor como instrumento vivo e como resultado da ação coletiva dos trabalhadores. Eram porta-vozes das necessidades, das lutas, dos desejos que cercavam o cotidiano dos operários. Informavam e ajudavam a formar o movimento operário e hoje nos permitem visualizar como viviam e agiam.

A imprensa não-operária também constitui imprescindível fonte de informações e de análise da realidade operária na República Velha, sendo um indicador do que pensavam os grupos que não eram operários a respeito das açōes desses.

Através dessa imprensa foi-nos possível colher dados a respeito do movimento operário em quantidade maior do que através da imprensa operária. Isso se deve ao fato de estar voltada ao público em geral e por não ter passado pelas dificuldade próprias da imprensa operária acima expostas.

O movimento operário deve ser entendido como um conjunto de ações desenvolvidas pelos trabalhadores, em nosso caso urbanos, que englobam atitudes conjuntas e/ou solitárias. Essas açōes podem ser: greves, boicotes, panfletagem, confrontos orais e físicos, enfim, são atitudes contestadoras à realidade por eles vivenciada.

As greves podem ser consideradas a maior expressão do movimento operário, onde se solidarizam em busca de soluções para as suas reivindicações.

As classes dominantes e os grupos operários de Rio Grande possuíam entendimentos diferenciados quanto à significação das greves.

As primeiras as entendiam como alterações da ordem, que deveriam ser neutralizadas e combatidas, pois eram atitudes provenientes de mentes indesejáveis e representavam ameaças e perigos para a manutenção da realidade que propagavam ser ordeira e próspera.

Para os operários era a forma de luta mais eficaz que possuíam. Mas havia entre o operariado visôes diferentes a respeito do significado do que a greve representava, dependendo da tendência que o grupo seguia. Para os socialistas a greve possuía um caráter reformista revolucionário. Já para os anarcossindicalistas, grupo predominante na época, a greve constituía-se na ação direta e na negação da participa- 
ção político-partidária, possuindo a função de desenvolver a solidariedade e a ação coletiva do grupo.

Enquanto o movimento operário estadual e nacional mobilizouse com maior intensidade durante os anos do primeiro conflito mundial, e sobretudo no ano de 1917, o operariado urbano riograndino teve nos anos de 1918 e 1919 a expressão maior de sua capacidade de mobilização.

A primeiro de outubro de 1918 a população riograndina despertou com a notícia de que os trabalhadores da Companhia Francesa do porto, encarregados da carga e descarga, haviam se declarado em greve na tarde do dia anterior.

Reivindicavam a diminuição das horas de trabalho, de dez para oito, e o aumento de $25 \%$ dos salários, desejavam receber por dia e não mais por hora.

A greve alastrou-se rapidamente, com a adesão de outras categorias, como o pessoal dos bondes elétricos, oficinas e Usina Elétrica.

Rio Grande vivia uma situação anormal com o não funcionamento dos bondes, sem energia elétrica e com os trabalhos no porto parados. A falta de energia elétrica deixou a cidade sem iluminação na noite anterior, desagradando à população e motivando sentimentos contrários aos grevistas.

$\mathrm{O}$ policiamento da cidade era aumentado à medida que novas categorias declaravam-se em greve. O reforço policial contava com praças das cidades vizinhas.

A repressāo ao movimento grevista iniciou no dia 3 , quando praças da Brigada Militar invadiram a sede da União Operária, impedindo a realização de uma reunião marcada para as 14 horas. Os operários reagiram enviando um telegrama ao presidente do estado: "Ao Dr. Borges de Medeiros: Dr. Presidente do Estado, Porto Alegre. Início greve, Dr. Nascimento apóia inteiramente conforme órgão oficial, agora sede invadida brigada arbitrariamente, ânimos exaltados, pedimos providências, continuar greve pacífica. União Geral dos Trabalhadores."

O apoio esperado pelos grevistas não foi conseguido, pois tanto o governo do estado como as forças públicas já conheciam vários líderes do movimento operário e assim tornava-se mais fácil neutralizar a atitude dos mesmos. Quanto à atitude do presidente do estado 
frente à greve, foi a de que o intendente municipal deveria agir de forma a sufocá-la.

No dia 4 apenas parte dos carroceiros e trabalhadores dos esgotos se encontravam trabalhando. Os estabelecimentos públicos e casas comerciais passaram a ser guarnecidos por forças estaduais e federais. As embarcações passaram a descarregar os produtos no porto de Pelotas, pois no de Rio Grande todos os serviços estavam paralisados.

Os grevistas fizeram circular dois boletins entre a população. Expressavam o que aspiravam e como entendiam aquele momento. $\mathrm{O}$ primeiro deles é datado de 3 de outubro e o segundo de 4 do mesmo mês.

\section{"Trabalhadores e Camaradas!}

Em face da exploração que nós os trabalhadores do porto éramos vítimas em consequiência das demasiadas horas de trabalho, que nos faziam trabalhar, desde o dia $1^{2}$ nos achamos em greve.

Entretanto não somos nós somente que sofremos com as conseqüências da situação presente, que torna a vida mais difícil do que nunca. Todos vós trabalhadores, sois explorados vilmente. Todos vós sois vítimas e, como vós a miséria e não raro a fome, é preciso pôr termo a esse estado de coisas.

É necessário que todos abandoneis o trabalho, tornando-vos solidários conosco na luta e nos benefícios que dela pode vir.

É necessário pois que a greve se torne geral. Que ninguém mais trabalhe enquanto não forem satisfeitas as nossas aspirações, que são também as vossas.

$\mathrm{O}$ que se pede são as oito horas de trabalho e de 10 a $25 \%$ de aumento na razão inversa dos ordenados.

Ficam convidados os padeiros, tecelóes, carroceiros e sapateiros, todos enfim que têm o nome de operários, para comparecerem na nossa sede hoje, $3 / 10$ à noite, $e$ amanhā, $4 / 10$ às 9 horas da manhã.

Prevenimos ao operariado que a sede é qualquer ponto aonde se reunirem as coletividades, desde que não possa ser na sede da União Geral dos Trabalhadores.

A greve geral camaradas! Viva a greve geral!

Viva as oito horas!

A comissão."

No panfleto do dia 4 foi publicado o desagravo dos operários com a invasão arbitrária à sede da União Geral dos Trabalhadores. Os operários pediam a união em torno das causas que levaram à greve e a 
libertação dos colegas presos. Pediam ainda que lhes fosse restituído 0 direito de reunião.

No dia 5 a greve se encaminhava para o fim, dependendo para a total volta ao trabalho a soltura dos dois operários presos e a reabertura da sede da União Geral dos Trabalhadores. A Companhia Francesa resolveu pagar os seus operários, mesmo os que estavam em greve. Ao mesmo tempo em que solicitou, junto aos escritórios da empresa em Paris, aumento gradativo para os salários, uma vez que os produtos consumidos pelos operários haviam aumentado assustadoramente.

Os operários presos eram Florentino Lima de Barros e Arthur Espírito Santo, a favor deles foi impetrado um pedido de habeascorpus no dia 5 de outubro. Estavam presos desde o dia 2, sob ordem do delegado de polícia.

A partir do pedido de habeas-corpus foi possível tomar conhecimento das razões da prisão. “(...) Os trabalhadores da Companhia Francesa, no dia $1^{\circ}$ deste mês, declararam-se em greve pacífica, tendo a União Geral dos Trabalhadores efetuado várias reuniões nesse sentido, com a assistência do Dr. intendente municipal (...). Acontece, porém, que, ante-ontem às 11 horas foram chamadas à presença da autoridade policial Florentino Lima de Barros e Artur Espírito Santo. Acudindo ao convite, compareceram à delegacia, recebendo nessa ocasião voz de prisão, sem que lhes fosse declarado o motivo da mesma. (....)."

O delegado de polícia respondeu, esclarecendo que os dois foram presos "por serem os promotores da greve com caráter agressivo e com o fim de praticarem depredações, o que de fato conseguiram fazer de surpresa no primeiro dia da greve, não tendo continuado nos seus fins sinistros devido a medidas acauteladoras tomadas pelas autoridades competentes"s. Segundo o delegado, a conservação dos mesmos na prisão era necessária, pois professavam idéias terroristas.

As idéias consideradas terroristas estão no panfleto entregue pelos grevistas, cuja escrita era em vermelho:

5 Processo Cível Crime Rio Grande $n^{2} 134$, Maço D, anos 1904-1922. 


\section{"União Geral dos Trabalhadores \\ Trabalhadores!}

\section{Povo!}

Como é de domínio público, as classes agremiadas nessa União Geral dos Trabalhadores, declararam-se em greve e têm se mantido em atitude pacífica.

Pede-se um pouco mais de descanso e mais um pedaço de pão. Reuniram-se os trabalhadores pacificamente em sua sede em sessōes públicas, onde até as autoridades assistiram os debates e os discursos dos grevistas.

Entretanto, apesar desta atitude pacífica, a nossa sede foi arbitrariamente invadida, as reunióes proibidas, isso contra todas as leis do país, contra a Constituição dessa decantada República democrática.

Assim, aqueles que se dizem mantenedores da ordem, investem contra as leis, expulsando de sua sede os trabalhadores que souberam conduzir-se com critério, por nâo julgarem conveniente a reação.

Contra essa violência inqualificável protestamos energicamente e reclamamos em nome da razão e da justiça o nosso sagrado direito de reunião e a liberdade de greve que a Constituição nos garante.

Pedimos, pois, ao operariado em geral que em sinal de protesto contra tais violências se declare em greve geral apoiando com esse ato enérgico as nossas aspirações justíssimas.

Irmão da luta e do sofrimento, à greve geral.

Que ninguém trabalhe enquanto não nos seja restituído o direito de reunião e a liberdade dos companheiros que se acham presos.

A greve continua firme. Os arreganhos da polícia e da brigada não nos afetam.

Mostremos que não somos covardes.

Tenhamos dignidade e energia.

VIVA A GREVE!

A comissāo."

O jornal Echo do Sul do dia 7 de outubro de 1918 publicava a soltura dos dois operários e o fim da greve com o retorno dos operários ao serviço.

Como conseqüência da greve, no dia 19 do mesmo mês os padeiros fundaram o seu sindicato.

Enquanto o jornal Echo do Sul se posicionou de forma simpática ao movimento grevista e responsabilizou as autoridades municipais 
pela falta de energia elétrica no primeiro dia da greve, o jornal Rio Grande, situacionista, responsabilizou os grevistas.

“(...) Mas assim como apreciamos o caráter pacífico dos acontecimentos, para provar que não estamos incondicionalmente ao lado dos grevistas, usamos as palavras da mais enérgica censura para a prática injustificável da violência que deixou a cidade em completas trevas durante uma noite inteira. Sem que circunstância alguma nos parecesse capaz de amparar $\mathrm{o}$ ato vandálico...

Não aplaudimos e jamais aplaudiremos açẫo alguma, que mesmo amparada por causas merecedoras de simpatias, leve os seus autores a se afastarem dos limites da ordem dentro da qual se deve manter os que reclamam justiça.

Os grevistas transpuseram os limites dentro dos quais podiam justificar as suas reclamações, enveredando pelo caminho da violência e procurando com ameaças dantescas, que a autoridade se sente no dever indeclinar com a máxima energia, chamar para sua causa elementos ordeiros de classes que se conservam inativas (...)"

O jornal O Tempo, apesar de ter criticado a ação dos grevistas por terem concitado os operários a aderirem à greve e por ter ficado a cidade sem iluminação devido à mobilização, não se posicionou a favor das autoridades locais, omitindo opinião sobre as mesmas.

$\mathrm{O}$ ano imediatamente posterior ao término do primeiro conflito mundial foi palco de manifestaçōes operárias, que a partir da segunda década do século diminuíram de intensidade. Era 1919 quando ocorreu a manifestação operária que marcou as duas primeiras décadas desse século.

O motivo que desencadeou a greve foi a troca do meio de transporte utilizado pela Companhia Francesa para levar os operários. Os operários se declararam em greve em dois de maio.

A Companhia Francesa concedia, até então, transporte diário para os trabalhadores do Novo Porto, feito por bondes em três horários e ao custo de três mil réis ao mês, por pessoa. Devido ao grande número de operários, a empresa substituiu os bondes por trens de carga destoldados.

Justamente quando os operários faziam a primeira viagem de trem, caiu grossa chuva e os mesmos chegaram molhados ao local de trabalho, abandonando-o e se dirigindo à sede da União Geral dos 
Trabalhadores para pedir apoio e encaminhar ofício à diretoria da empresa solicitando a reconsideração da medida.

Como não obtiveram resposta ao ofício, os operários procuraram a direção da Companhia Francesa e essa lhes informou que não havia bondes suficientes para o transporte dos operários.

Resolveram permanecer em greve e incluir na pauta de reivindicações a diminuição das horas de trabalho sem restrições nos vencimentos.

Os jornais pesquisados foram unânimes em tecer elogios à diretoria da empresa. Publicaram que a mesma transportava seus operários sem que lhes fosse obrigatória a prestação de tal serviço, que passou a usar trens por terem maior capacidade e que estava providenciando para que as duas chatas destoldadas fossem cobertas. Os bondes ofereciam lugar para 700 pessoas e o número de operários transportados era de 2.500 , a capacidade ofertada pelos trens era maior.

Quando os grevistas acrescentaram as reivindicações de diminuição das horas de trabalho, o movimento passou a contar com a simpatia apenas de dois jornais. O acréscimo dessa reivindicação estimulou o jornal Rio Grande a escrever no dia 15 de maio, contra os grevistas:

"Fácil é perceber a causa dessa brusca mudança, em primeiro lugar os promotores do movimento não queriam perder o pretexto achado para execução desses planos criminosos, e por isso trataram de embaralhar as coisas desviando a atenção dos trabalhadores da questão dos transportes, de fácil solução.

E em segundo lugar, viram eles, que, aquela questão era de simples interesse dos trabalhadores do porto, ao passo que, a de oito horas poderia interessar aos trabalhadores em geral aumentandolhes o campo de exploração."

(Rio Grande, 15/5/1919)

Ao se referir à sede da União Geral dos Trabalhadores, o mesmo jornal a chama de "casa suspeita". O jornal posiciona-se claramente contra a greve, usando termos pejorativos e agressivos ao se referir ao movimento, ao mesmo tempo que defende a ação das autoridades.

Os operários, por outro lado, mostravam suas habilidades em outros setores, estabelecendo um programa para a greve: 
" $1^{2}$ a greve será dirigida por um comitê central que identificará e intensificará a mesma;

$2^{9}$ o comitê tratará da jornada de oito horas de trabalho sem diminuiçẫo dos salários atuais;

$3^{\circ}$ o horário para todos os trabalhadores em greve será o seguinte: das 7:30 às $11: 30$ e das $13: 30$ às 17:30;

$4^{9}$ toda a vez que os patrôes necessitarem que os operários trabalhem mais de 8 horas, pagarāo $50 \%$ de extraordinário;

$5^{\mathrm{o}}$ todos os trabalhadores que antecederem das 7:30 e se excederem das 17:30, serāo considerados com direitos a vencimentos extraordinários;

$6^{\circ}$ a Uniāo Geral dos Trabalhadores nomeará delegados em todas as sessōes que julgar conveniente a fim de fiscalizar as condiçōes acima prescritas;

$7^{\circ}$ a greve só poderá se solucionada mediante a negociações entaboladas, pessoalmente ou por escritas, com o comitê central da União Geral dos Trabalhadores."

(Echo do Sul, Rio Grande, O Tempo maio de 1919)

Diariamente novas categorias aderiam ao movimento grevista, pois as reivindicações diziam respeito aos operários em geral.

Através das informações publicadas no Echo do Sul, de 6 de maio, constata-se a razão pela qual foi acrescida a questão das oito horas de trabalho. Entendiam os operários que, como passaram a ser transportados por trens de carga e que estes não passavam pelos mesmos pontos que os bondes, precisavam locomover-se por distâncias maiores, perdendo mais tempo e cansando-se mais, daí pedirem a diminuição das horas de trabalho. Estavam descontentes também pelo fato de a medida ter atingido aos trabalhadores da Companhia Francesa que trabalhavam no Novo Porto, sendo que a empresa continuava a oferecer os bondes para os operários do Frigorífico Swift.

Mesmo sendo transportados por bondes ao Frigorífico Swift, os operários aderiram à greve no dia 6 de maio. Nesse mesmo dia os estivadores fizeram causa comum ao movimento, reivindicando aumento salarial e oito horas de trabalho.

A sede da União Geral dos Trabalhadores passou a ser um dos lugares mais freqüentados naqueles dias. Reuniam-se inúmeros trabalhadores para tratar de assuntos referentes à greve, como o programa que foi enviado aos diretores do Frigorífico Swift. O programa estabelecia oito horas de trabalho diárias, que todos os operários que trabalhassem mais de oito horas ganhariam mais $50 \%$ sobre seus ordena- 
dos, que a Companhia ficaria obrigada a admitir os operários grevistas que tivessem se portado dentro da ordem, que os atuais salários deveriam ser mantidos com a diminuição das horas trabalhadas e que a solução para o término da greve se daria entre os membros do comitê grevista e a direção da empresa.

À medida que novas categorias aderiam ao movimento grevista, as autoridades municipais reforçavam as forças policiais com praças de outras localidades.

Mesmo sendo importante a adesão de mais operários para o sucesso da greve, o comitê central dispensou o apoio do pessoal da Usina Elétrica, para que a população não fosse prejudicada.

No dia 7 de maio os operários da Ítalo-Brasileira, das oficinas mecânicas do senhor M. José Fernandes e os funcionários da Viação Férrea aderiram ao movimento.

Nessa mesma ocasião os serviços telegráficos foram censurados, limitando a ação e a liberdade da União Geral dos Trabalhadores, que ficou impedida de comunicar-se com as associações operárias de outras cidades.

A censura se manifestou também através da repressão às manifestações operárias, como a que ocorreu a um operário que entregava boletins alusivos à greve em frente à fábrica União Fabril e Rheingantz. O operário foi abordado por um policial, que arrebatou-lhe os panfletos e, insultando-o, ameaçou-o de prisão. Outro exemplo foi a ação do delgado de polícia, que prendeu um operário que integrava um grupo que dava vivas às oito horas de trabalho em frente à Rheingantz.

Como ação de repressão à greve a sede da União Geral dos Trabalhadores foi invadida por policiais armados, que ameaçaram aos que ali se encontravam.

No dia 7, um grupo de grevistas fazia piquete em frente à fábrica União Fabril com o intuito de conseguir adesão de seus colegas, quando foram agredidos por praças da polícia, "erguendo um operário presente, um viva às oito horas de trabalho, tanto bastou para que um numeroso esquadrão da polícia que ali se achava, naturalmente com a obrigação de manter a ordem, fizesse uma carga contra os indefesos, como dissemos acima, dentre os quais se achavam numerosas mulheres" (Echo do Sul, 8/5/1919).

Sobre o fato, o jornal Rio Grande menciona que os policiais foram agredidos pelos grevistas e elogia a atitude da força pública. 
"Ainda ontem quando agredidos a pedradas (...), ainda assim foi elogiável a sua tolerância que a muitos pode parecer censurável. Não tendo querido até agora usar de meios violentos, embora as ordens superiores que tem para tal, a eles recorrerá a força da polícia e brigada, para reprimir com energia todo o excesso de parte dos grevistas.”

A posição do $\mathbf{O}$ Tempo é diferente, "a polícia enveredou ontem pelo mal caminho", lembrando que os operários têm mantido atitudes pacíficas, "ganhando de tal maneira numerosas adesões pessoais à sua causa".

Aderiram ainda ao movimento o pessoal dos esgotos, motorneiros, condutores de bondes, operários da Cervejaria Schmitt, parte dos operários da fábrica Leal Santos, os operários da fábrica de Charutos Pock.

A situação agravava-se a cada momento, o que levou a polícia a estabelecer o fechamento dos restaurantes e botequins às 22 horas, a título de evitar tumultos.

Durante o dia 8 de maio os grevistas fizeram piquetes em frente à União Fabril, à fábrica de Charutos Pock e foram agredidos pela polícia.

A União Geral dos Trabalhadores convocou, através de boletins distribuídos profusamente, todas as classes trabalhadoras para uma reunião popular que se realizaria às 15:00 daquele dia, na Praça General Teles.

Saíram de frente da União Geral dos Trabalhadores em direção à Praça General Teles cerca de três mil operários, contando com várias mulheres e crianças que faziam a vanguarda do préstito. Uma operária carregava a bandeira da sociedade. O cortejo seguia sem excessos, erguendo de quando em vez vivas à greve e às oito horas de trabalho.

Ao passarem em frente à Praça Tamandaré deu-se o conflito com a polícia, que os acompanhava a certa distância.

Segundo notícias publicadas nos jornais Echo do Sul e O Tempo, o sargento ordenou que fosse dado toque de corneta para que os policiais se aproximassem e intimassem os grevistas a se dispersarem. Como esses não atenderam à ordem, "o esquadrão fez tremenda carga sobre os populares, dos quais os mais acossados foram as mulheres que marchavam à frente. Não contentes com isso, os soldados da brigada descarregaram as armas sobre a multidão esbalderando impiedosamente a torto e a direito. (...). Homens, mulheres e crianças corriam 
desesperados em todas as direções acossados pelos estouros dos implacáveis milicos." 6

Continua a narrar os fatos com claro posicionamento a favor dos operários:

"Os estabelecimentos comerciais e as casas particulares das circunvizinhanças foram invadidas pelos populares em fuga e tiveram que fechar as suas portas.

Outros abrigaram-se atrás das árvores existentes na praça. Ainda outros empoleiraram-se em cima das mesmas a fim de escapar a sanha policial.

Duas moças e alguns rapazes na precipitação da fuga, atiraram-se no lago que circunda aquele logradouro público.

Ao mesmo tempo o sargento da brigada arrebatava das mãos de uma senhorita o estandarte da União Geral dos Trabalhadores (...).

Houve uma menina que atordoada para escapar, saiu debaixo da barriga de um cavalo montado por um praça da brigada militar".

(Echo do Sul, 8/5/1919)

Numeroso grupo de operários, ao retirar-se da praça, se dirigiu para a sede da União Geral dos Trabalhadores, onde novos fatos se desenrolaram.

Os grevistas foram avisados de que forças da Brigada Militar e da polícia administrativa se dirigiam para o local. "Diante dessa insólita agressão e na eminência de verem o edifício de sua sociedade atacado pela força pública, os grevistas resolveram reagir à bala, disparando contra aquela alguns tiros de revólver."

Do confronto resultou um morto e vários feridos, que foram atendidos na Assistência Pública. O morto foi o pedreiro Delfim José de Castro, casado, pai de duas filhas e com 47 anos de idade. Os jornais foram unânimes em afirmar que ele não estava participando da greve e passava despreocupadamente pelo local quando foi atingido e vitimado. Dentre os feridos mencionam o nome de dez operários, sendo que havia outros, e de um praça.

Após o tiroteio a sede da União Geral dos Trabalhadores teve suas portas lacradas pela polícia, que se manteve em guarda durante aquela noite. No dia seguinte foi fechada a sede da Sociedade dos Marinheiros e Remadores e passaram a ser guarnecidos os edifícios

Echo do Sul, 8/5/1919. 
públicos federais, o Novo Porto, as estações da Viação Férrea e a Usina Elétrica.

A versão para os fatos dada pelo jornal Rio Grande foi a seguinte:

"Vinha grande número de grevistas à Praça General Teles em atitude hostil para a realização de um meeting, quando as autoridades no intuito de evitar o comício, dado a sua intenção pretensiosa, intimidaram aqueles a se dispersar (...)."

(Rio Grande, 9/5/1919)

Ainda no dia 9 de maio de 1919 o Rio Grande publicou o panfleto distribuído pela União Geral dos Trabalhadores convidando para o comício do dia anterior:

"Convida-se a todas as classes trabalhadoras da cidade de Rio Grande para comparecerem hoje, às 14 horas, duas da tarde, na sede da União Geral dos Trabalhadores, e desta seguirá um préstito à praça General João Teles, para protestarmos contra as infâmias da polícia. Pela União Geral dos Trabalhadores

A Comissão."

Como a maioria das associações operárias estava fechada por ordem militar, o advogado Carlos Machado requereu junto ao juiz uma ordem de habeas-corpus para que as sedes fossem reabertas permitindo aos operários se reunirem em locais convenientes. O juiz não deferiu o pedido.

Devido ao clima de intranqüilidade em que se encontravam os cidadãos riograndinos, a fábrica União Fabril fez publicar nota nos jornais locais esclarecendo o que entendiam seus diretores ter ocorrido nos dias 7 e 8 em frente à empresa. Na nota esclarecem que seus operários estavam sendo intimados pela atitude ameaçadora da multidão de operários estranhos e por isso desistiram de entrar na fábrica.

No dia 9 de maio o jornal Rio Grande veiculou notícia de que as fábricas União Fabril, Tecelagem Ítalo-Brasileira e Charutos Pock fecharam as suas portas por tempo indeterminado, pois seus operários estavam sofrendo coações dos grevistas.

Ainda no dia 9, um grupo de trabalhadores inutilizou uma válvula de água que abastecia a Companhia Swift, pretendendo interromper o trabalho naquele estabelecimento, fato não ocorrido, pois o reservatório da empresa forneceu água suficiente para a realização dos trabalhos. 
O jornal Echo do Sul, em 10 de maio, publicou que policiais perseguiam grevistas em bares e praças públicas, ameaçando-os e intimidando-os a se retirarem.

Os jornais O Tempo e Echo do Sul responsabilizaram o delegado de polícia pelos fatos e inocentaram os policiais, pois estes estavam agindo sob as ordens daquele. "A culpa inteira, absoluta, tem no indivíduo que exerce aquele cargo sem penetração, sem discernimento de inteligência, com a noção a mais apagada de seu dever, confundindo energia com brutalidade."

A tensão na cidade aumentava, a prova disso foi o aumento do efetivo policial com cerca de 90 praças e um navio de guerra da Marinha Nacional.

Os operários em greve convidavam para reuniões e contavam com o apoio dos bombeiros que aderiram ao movimento ao serem intimados a vigiar a população.

$\mathrm{O}$ clima de tensão transparecia nos boletins distribuídos à população, tanto pelas forças públicas como pelos grevistas:

\section{"AVISO AO POVO!}

As autoridades civis e militares hoje reunidas, resolveram pedir e como pedem às pessoas pacíficas e bem intencionadas, se absterem de tomar parte em manifestações externas de qualquer natureza, visto que, cumprindo determinaçōes superiores, não permitirão de forma alguma, a menor alteração da ordem pública, bem como qualquer coação à liberdade de trabalho.

Perfeitamente aparelhadas para a manutençăo da ordem e na garantia da lei, as autoridades confiam na índole ordeira da população."

(Echo do Sul, 12/5/1919)

Por sua vez os grevistas distribuíram boletins, pedindo ao operariado que se mantivesse em greve, pois somente através da união conseguiriam a vitória: 


\section{"TRABALHADORES! POVO!}

A polícia massacrou os filhos dessa terra fazendo o batismo de sangue.

A constituição e as leis são um trapo de papel.

A autoridade que desrespeitou a lei é criminosa, nāo é mais autoridade.

O povo que lutava pacificamente pelos seus direitos foi massacrado. Deverá o povo desistir de suas aspiraçōes? Deverá voltar para trabalhar novamente $10 \mid 11$ horas por dia? Deverá voltar a casa tornando inútil o esforço já feito?

Não e não!

A polícia semeou o vento que colheu a tempestade.

É preciso ir até o fim. Não recuar covardemente.

Ninguém volte ao trabalho, que a vitória será certa.

E que cada um faça o que puder e julgar conveniente para o triunfo de nossa causa.

Se a constituição é um farrapo e a liberdade de reunião uma mentira, que se reunam os grupos e ajam como puderem.

VIVA A GREVE! VIVA AS OITO HORAS!"

O outro boletim distribuído pelos operários clamava pela união e lembrava a resignação dos mesmos:

\section{"Companheiros!}

Companheiros do conforto, resignação nos dias amargos porque passa a nossa gente.

Filhos do trabalho presdestinados a um futuro de luz e de progresso, seremos vitoriosos na ordem, pela ordem e dentro da ordem, embora queiram levar ao dimedir[?] da amargura.

Nada de desordens, operários.

Fazeis sempre como tendes feito até agora, porque aos homens bons Deus protege.

$\mathrm{Na}$ greve continuam resistentes. No frigorífico estão trabalhando somente diversos carneiros, porque dia e noite os companheiros vão abandonando o trabalho.

Na segunda-feira os burgueses da Companhia Francesa e do Frigorífico esperam não para trabalhar, rindo da nossa miséria, pois que eles esperem pela outra segunda-feira, porque o brio do operário não deve satisfazer a vontade da burguesia.

Estejamos firmes companheiros!" 
No dia 14 algumas categorias começaram a voltar ao trabalho. Muitos operários voltavam a trabalhar, mas não nos locais anteriores, como os funcionários demitidos do Frigorífico Swift, que passaram a trabalhar na Companhia Francesa.

Ainda nesse dia, quatro operários grevistas agrediram funcionários da Barraca Thompsen que não tomaram parte no movimento grevista.

A imprensa noticiou, no dia 17 de maio, o fim da greve.

Os operários Miguel de Gusmão, secretário da União Geral dos Trabalhadores, e Francisco Calada Iuti, que se achavam presos desde o dia 8, foram postos em liberdade. As chaves das associações operárias foram devolvidas, bem como o estandarte arrebatado das mãos de uma operária durante o préstito do dia 8.

Para os grevistas a greve trouxe como resultado o atendimento das reivindicações de algumas categorias.

Nos meses posteriores a tensão ainda se fazia sentir. No mês de julho dois guardas do Frigorífico Swift agrediram, sem motivo aparente, dois operários.

Como demonstração de desagravo à persistência da situação dos trabalhadores como elementos desprovidos de garantias, a imprensa continuava a publicar notícias sobre o meio operário.

O ano de 1919 marcou com greves várias cidades. Em Rio Grande a concentração de forças nos conflitos tomou vulto nunca antes vivenciado pela população e demonstraram a organização do operariado. 